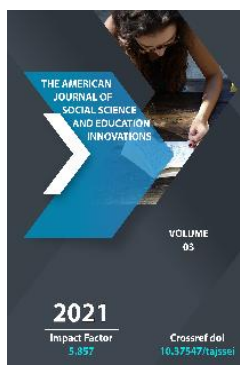

\title{
Peculiarities Of Education Technologies
}

\author{
Y. Nurumbekova \\ Doctor Of Philosohy (PhD) On Pedagogical Sciences, Gulistan State University, Uzbekistan
}

Copyright: Original content from this work may be used under the terms of the creative commons attributes 4.0 licence.

\section{ABSTRACT}

In educational institutions of the world, when training teachers in the educational process, mechanisms have been introduced to ensure the relationship and organic relationship of education and upbringing, to expand the pedagogical and psychological capabilities of spiritual-moral competence. In countries such as the United States, England, Germany, Japan, France, and Russia, special attention is paid to improving the system of spiritual-moral training of future teachers. In higher educational institutions, as part of the improvement of professional pedagogical activity, scientific research is carried out on the formation of spiritual-moral qualities of future teachers, the implementation of the system of their diagnostics, and ensuring organic compliance with spiritualmoral qualities. Scientific research is being carried out to develop effective organizational and pedagogical mechanisms for training teachers based on rich national cultural and historical traditions, customs and universal values, and to ensure the priority of humanization of education.

\section{KEYWORDS}

Implementation, technology, spiritual-moral qualities, psychology, axiology, pedagogy.

\section{INTRODUCTION}

The introduction of pedagogical technologies in the Republic is coordinated with the content of national education. The material and technical base for improving the system of 
spiritual-moral training of future teachers has been created, as well as normative and legal acts related to theoretical and methodological issues. The Decree of the President of the Republic of Uzbekistan No.4947 from February 7, 2017 "On the Strategy of actions for the further development of the Republic of Uzbekistan" on the priority direction "Development of the social sphere" provides"...improving the quality of General secondary, secondary special and higher education and implementing measures for their development", which defines one of the important tasks of the development of spiritual-moral qualities of future teachers. The solution of these problems is directly related to the correct solution of the problem of spiritualmoral development of the younger generation in society. As a result, opportunities for improving the system of spiritual-moral training of future teachers for educational activities have been expanded.

This thesis serves to a certain extent to implement the tasks defined in the Resolutions of the President of the Republic of Uzbekistan No. 2909 from April 20, 2017 "On measures for further development of the higher education system”, No. 4307 from May 3, 2019 “On additional measures to improve the effectiveness of spiritual and educational work", five important initiatives to establish a new system of social, spiritual and educational work at a video conference chaired by the President of the Republic of Uzbekistan Shavkat Mirziyoyev on March 19, 2019, dedicated to "issues of increasing attention to young people, their broad involvement in spiritual development, art and sports, the formation of skills for the correct use of information technologies, promotion of reading books among the younger generation and ensuring the employment of women" and other legal acts related to this activity.

\section{Tasks of the research are:}

- To study the current state of the problem on the basis of a systematic approach, to determine the forms, methods and tasks aimed at solving it;

- To expand the pedagogical possibilities of the content, conditions, factors, and means of integrating the system of spiritual-moral training of future teachers for educational activities, and innovative axiological approaches to the educational process;

- To improve the content of spiritual-moral qualities (requirements) for educational activities based on the priority of the content of the national cry;

- Improve the model of spiritual-moral training of future teachers based on optimization of personal and professional qualities.

The scientific novelty of the study is as follows:

- The spiritual-moral qualities of future teachers were improved using an axiological approach based on the transformation of the interiorization of universal values with the dialectical unity of the cognitive, sensory, social and individual in the individual;

- Improved by factor analysis and determining the statistical value of the dynamics of features and qualities, such components as humanism, education, patriotism, tolerance, love for children, characteristic of the educational activities of future teachers;

- Improved on the basis of integration of the algorithm and the professionogram of the 
structure of educational work of future teachers, the activity of the school "Mentor-pupil";

- Improved model of the system of spiritualmoral training of future teachers on the basis of mutual optimization of personal and professional qualities.

The reliability of research results is determined by their scientific and practical validity, based on the results of educational activities of educators of groups and microgroups, on the basis of philosophical, methodological, methodological, axiological, psychological and pedagogical approaches to the problem, as well as national and foreign experience of spiritual and professional development; the use of appropriate research tasks and complementary research methods; analysis and number of studies conducted; quantitative and qualitative security of the analysis and research characteristics; representativeness of experimental works and processing of the results obtained using methods of mathematical and statistical analysis.

The scientific significance of the research results is determined by the enrichment of the system of spiritual-moral training of future teachers with theoretical approaches; the development of criteria and indicators for determining the level of development of students ' spiritual-moral qualities and providing a positive solution to the problem of this study of scientific and methodological recommendations.

The practical significance of research results is determined by the possibility of their use in the development of a model of training future teachers to educational activity and improved modules (the small module, the primary module, micro-module) improved qualification requirements, work programs on General and special disciplines in designing educational hours, information hours and events in the system of continuous education, development of moral rules, and their use outside of class time, training and professional development of higher education teachers.

The introduction substantiates the relevance and necessity of the thesis topic; shows its connection with the priority areas of development of science and technology in the Republic, highlights the degree of study of the problem, defines the goals and objectives, the object and subject of the study, sets out methods, scientific novelty and practical results of the study, the reliability of the results, their scientific and practical significance, provides information about their implementation in practice, publication, structure and scope of the thesis.

The article describes the relationship between the development of national independence thinking and the development of students ' spiritual-moral qualities, pedagogicalpsychological, axiological factors for improving the training of future teachers for educational activities, as well as the state of development of spiritual-moral qualities in students.

The qualities of humanism, patriotism and hard work in the history and development of pedagogical thought of the Uzbek people in all historical periods formed the basis of education. The Resolution of the Cabinet of Ministers of the Republic of Uzbekistan dated January 10, 2015 No. 3 "on amendments and additions to the resolution of the Cabinet of Ministers of August 16, 2001 No. 343" on approval of state educational standards of higher education states that the main types of 
professional activities of graduates of the bachelor's direction in the field of pedagogical education of higher educational institutions should include pedagogical, research, spiritual and educational, organizational and managerial activities, and so on.

The phenomenon of improving the educational process and the system of spiritual-moral training of future teachers for the educational process is a very broad conception the basis of a scientific approach, the specific features of national and universal education are theoretically analyzed. In particular, as stated in the theory of Freud, "...the child, being a creature with needs, cannot control his energy due to helplessness." It follows That Freud's views do not refer to the age, gender, and individual psychological characteristics and physical capabilities of the child. According to the views of J.G. Mid "... as social beings, children develop primarily by imitating the actions of others. One form of imitation is play. In most cases, children imitate adults in their games." However, even in this theory, there is a one-sidedness in the expression of the features of the child's upbringing in the content of its formation as a person. According to such scientists who carried out a comparative analysis of the culture of education of the East and the West, as $\mathrm{H}$. Abdukarimov, M. Ashurov, M. Kuronov, O. Musurmonova, N. Egamberdieva, B. Rakhimov, D. Ruzieva, Z. Solieva, Sh. Olimov, A. Kholikov, Eastern moral values are based on tradition, while Western behavior has an individualistic character. In particular, in the research of H.I. Ibragimov and Sh. Abdullayeva justifiably shows that the educational process has such aspects that distinguish it from education as versatility, duration, its implementation on a holistic and concentrated basis, two-way properties and many contradictions. Joining the opinion of these scientists, we paid attention to the pronounced differences indicated above in the technological process.

According to preliminary data obtained during the ascertaining experiment, it was found that 15-18 percent of children do not want to go to school, 26-27 percent of children and their parents are not satisfied with the level of knowledge and education provided by the school, 7-8 percent of children have a desire to get deep knowledge, but they also want to hire Tutors for further education. This shows the need to carry out propaganda work among parents in cooperation with teacherseducators.

The analysis of the conducted questionnaires and pedagogical observations confirmed that the working day of high school students studying in professional colleges, academic lyceums and students of pedagogical faculties is at least 10-12 hours, of which 8-10 hours are occupied by the learning process, 3-4 hours are spent preparing homework, visiting Tutors, preparing for exams, that the main time is spent on studying and completing educational tasks, and the attention to "didactic" education increases.

In the course of the study, 112 plans for educational work were studied. in the result, it was found that 79 educators prepared these plans formally, in order to get the signature of the Director or Deputy Director for spiritual and educational work. It is determined that the essence and content of the work, the sense of responsibility for the timing of work, professional duty, as well as responsibility in General, in many cases were of secondary importance. 
Interviews and observations conducted with 860 students of various courses of higher education institutions showed that 8.0 percent of them (70 students) constantly smoke, and 17.6 percent (more than 150 students) are inclined to drink. It is concluded that this circumstance may lead to a violation of the professional behavior of future specialists and a change in the gene pool. Our research has shown that improving the spiritual-moral preparation of future teachers for educational work is a requirement of time and making it necessary to implement the educational process in accordance with a certain system and aimed at a certain goal plans and programs. From this point of view, the preparation of students for educational activities is also the result of a certain pedagogical system, which, as a set of goals, content, principles, laws, methods and means for the implementation of spiritual-moral training of future teachers for professional educational activities, is based on innovative technological approaches.

Pedagogical technique is a set of forms for improving the professional behavior of the teacher-educator; external expression of the internal content of the professional behavior of the teacher-educator; requirements for compliance with professional conduct standards based on external and internal criteria. The study highlights approaches to improving pedagogical technologies and pedagogical techniques aimed at determining the professional essence of the educational process (table 1).

\section{Comparative analysis of the manifestation of pedagogical techniques of students and students (a total of 420 students)}

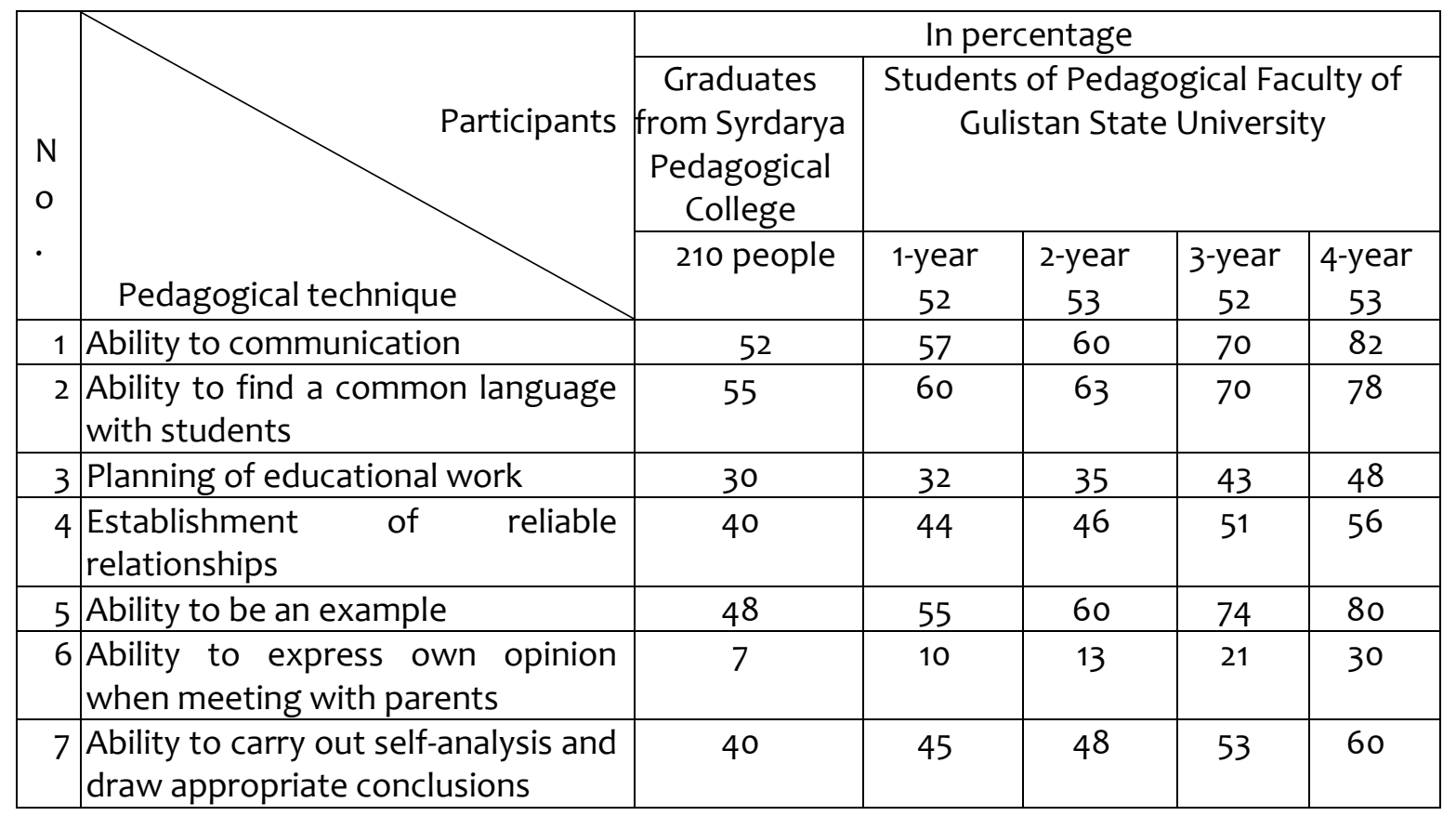


As can be seen from the table, the ability to communicate among students in teacher training colleges and University students is relatively good.

However, the ability to find a common language among College graduates is 55 percent, and students 78 percent. However, independent planning of educational work (educational classes and events) in both institutions does not reach even 50\%. A formative stage of our research such a situation shows that the efficiency of the process associated with how future teachereducator was able to embody the mastery of pedagogical techniques, the need for a preparatory process before the implementation of practices to re-perform practical knowledge of the student and of the student in education, to provide, in cooperation with scientists, educators, professionals, Methodists necessary recommendations, based on innovative approaches.

Topics that express the improvement of spiritual-moral training of future teachers for educational activities are studied in the form of modules. Each topic is presented as a small module, that is, it includes the units inherent in educational technology, and reflects the elements of interactive methods. In addition, there are different modules that make up the means of education and upbringing, the module on the experience of using interactive methods, and the module aimed at solving problem situations.

The organization of modules based on topics (materials) technology education helped to create a number of facilities to ensure efficient achievement of the purpose of education: systematization, organization of scientific- practical basis of educational activities of teachers; improvement of education on the basis of education; to raise cooperation "student - teacher", "educator - student" to the level of "subject - subjective" relations; the implementation of educational work (educational sessions) as education; increase of social activity of students in the technological process; provide training of qualified competitive personnel.

According to the purpose of the study, the development of pedagogical knowledge and the essence of pedagogical activity is studied on the basis of the principle of unity of education and upbringing. At the same time, the professorial formation of a teachereducator is associated with the level of certain individual qualities and personal professional qualities according to the results of our research, it is determined that these qualities consist of strong-willed, intellectual, emotional, practical qualities and selfmanagement. Our observations have shown the need to develop a holistic module of concepts related to improving the spiritualmoral training of future teachers for educational activities. This process has an integrative character, which provides, along with the requirement of individual knowledge from future teachers, as well as in a certain sense, teaching students to work based on the analysis of concepts. Conversations with students showed that learning to work based on the analysis of concepts requires a kind of methodological knowledge. Observations confirmed that students, thanks to their operational memory, respectively memorizing what they saw and heard, have the ability to quickly remember, but find it difficult to scientifically justify the meaning of concepts, explain their essence. Only when the student 
realizes in a timely manner what the content of the concept is aimed at, a sense of patriotism and respect for national values will increase.

Each concept related to the educational activity of the student serves as a basis for the development of his logical thinking and development on this basis, the development of analytical (scientific, educational, methodological, practical, self-educational) abilities corresponding to analytical thinking. The essence of innovative pedagogical factors is also based on the creation of innovations from these concepts. Accordingly, the essence of the innovative approach peculiar to research is as follows: analysis of concepts related to educational activities; introduction of these concepts into the content of the acquired knowledge; creation of innovations related to educational activities from the concepts; development of logical thinking; essence of the innovative approach; development of analytical thinking; pedagogical and psychological factors; development of pedagogical ability; factors related to special disciplines and methods.

This model is based on the principle of unity of education and upbringing in the process of personal-oriented education.it is based on the spiritual-moral aspects of future teachers and educators. Improving the quality of spiritualmoral training of future teachers for educational activities is directly related to its content for this purpose, the teacher must first ensure the synthesis of theoretical and practical knowledge. The effectiveness of the educational process is ensured only when pedagogical knowledge is integrated with pedagogical techniques and pedagogical technologies.
It follows from the foregoing that the research process based on the structure of professional, pedagogical, psychological, technological activities of future teachers and educators a systematic job analysis of the educational activities of the individual personality of a future teacher-educator, as well as criteria for evaluating the activities of the teacher and the teacher in the innovation process based on the organic correlation algorithm structure of educative activities and professional graphic experience the personality of a future teachereducator, and on this basis, the charter of the school "Mentor-student" has been improved.

The research was carried out in three stages in the course of 2008 - 2018; the first stage-the ascertaining experiment (2008-2011) - studied the existing state (860 students and 212 teachers took part). At the second stage-the formative experiment (2011-2014), a research methodology was developed, experimental work was carried out according to the developed methodology (more than 200 classes and educational activities were analyzed, more than 420 students participated), and innovative pedagogical factors related to improving the training of future teachers for educational activities were determined. Received the third-the final stage of the experiment (with the participation of 336 students from the pedagogical faculties Gulistan State Univeristy, Bukhara State University, Fergana State University, 20142019) data were analyzed using mathematicalstatistical method; the results are summarized, defined performance indicators, developed by General conclusions and recommendations for experimental work.

In accordance with this, the external and internal (reflexive) features of each stage are studied and implemented, which are 
The American Journal of Social Science and Education Innovations (ISSN - 2689-100x)

Published: March 25, 2021 | Pages: 201-211

Doi: https://doi.org/10.37547/tajssei/Volume03Issue03-28

expressed on the basis of the dynamics of the technology of professional activity of the educator as follows (table 2).

Table 2

Table of calculations based on results at the end of the experiment

\begin{tabular}{|c|c|c|c|c|c|c|}
\hline \multirow{2}{*}{$\begin{array}{l}\text { Criterion of professional qualities } \\
\text { and properties inherent in the } \\
\text { educational activities of future } \\
\text { teachers }\end{array}$} & \multirow[b]{2}{*}{$\chi_{\text {kузатуль }}^{2}$} & \multirow[b]{2}{*}{$\chi_{\text {критик }}^{2}$} & \multicolumn{2}{|c|}{$\begin{array}{c}\text { The average } \\
\text { value }\end{array}$} & \multirow[b]{2}{*}{ 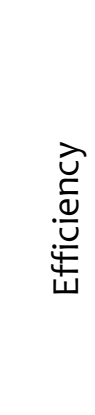 } & \multirow[t]{2}{*}{ Conclusion } \\
\hline & & & 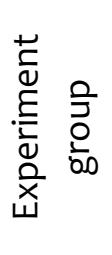 & $\begin{array}{l}0 \\
0 \\
0 \\
00 \\
0 \\
0 \\
\frac{1}{L} \\
0 \\
0\end{array}$ & & \\
\hline 1. Erudition & 76,31 & 5,99 & 4,08 & 3,63 & 1,13 & $\mathrm{H}_{1}$ \\
\hline 2. Humanism & 77,65 & 5,99 & 4,07 & 3,62 & 1,13 & $\mathrm{H}_{1}$ \\
\hline 3. Love for children & 78,52 & 5,99 & 4,06 & 3,60 & 1,13 & $\mathrm{H}_{1}$ \\
\hline 4. Professional responsibility & 78,08 & 5,99 & 4,05 & 3,59 & 1,13 & $\mathrm{H}_{1}$ \\
\hline 5. Loyalty to professional duty & 79,04 & 5,99 & 4,04 & 3,57 & 1,13 & $\mathrm{H}_{1}$ \\
\hline 6. Patience & 80,04 & 5,99 & 4,03 & 3,56 & 1,13 & $\mathrm{H}_{1}$ \\
\hline 7. Eloquence & 79,86 & 5,99 & 4,02 & 3,55 & 1,13 & $\mathrm{H}_{1}$ \\
\hline 8. Modesty & 79,70 & 5,99 & 4,01 & 3,54 & 1,13 & $\mathrm{H}_{1}$ \\
\hline $\begin{array}{l}\text { 9. Correspondence of words to } \\
\text { the dictates of the soul }\end{array}$ & 78,24 & 5,99 & 4,00 & 3,53 & 1,13 & $\mathrm{H}_{1}$ \\
\hline 10. Creative search & 78,13 & 5,99 & 3,99 & 3,52 & 1,13 & $\mathrm{H}_{1}$ \\
\hline 11. Professional skills & 79,28 & 5,99 & 3,98 & 3,51 & 1,13 & $\mathrm{H}_{1}$ \\
\hline 12. High spirituality & 77,79 & 5,99 & 3,97 & 3,50 & 1,13 & $\mathrm{H}_{1}$ \\
\hline Total & 78,37 & 5,99 & 4,02 & 3,56 & 1,13 & $\mathrm{H}_{1}$ \\
\hline
\end{tabular}

It follows that the experimental work carried out in the selected experimental groups was more effective by 1.13 times in relation to the control group. mathematical and statistical 
methods proved that their overall average growth was 13 percent higher.

Calculations on the level of planning by students of educational classes and educational activities in the process of pedagogical practice on the basis of an innovative axiological approach are given (table 3).

Table 3

\begin{tabular}{|c|c|c|c|c|c|c|}
\hline \multirow[b]{2}{*}{ Criteria } & \multirow[b]{2}{*}{$\chi_{\text {уззаmу夕 }}^{2}$} & \multirow[b]{2}{*}{$\chi_{\text {критик }}^{2}$} & \multicolumn{2}{|c|}{ The average value } & \multirow{2}{*}{ 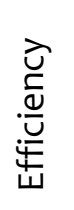 } & \multirow[t]{2}{*}{ Conclusion } \\
\hline & & & 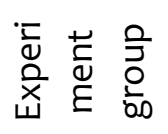 & 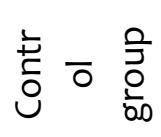 & & \\
\hline $\begin{array}{c}\text { At the beginning of the } \\
\text { experiment }\end{array}$ & 0,05 & 5,99 & 3,82 & 3,84 & 1,00 & $\mathrm{H}_{\mathrm{o}}$ \\
\hline At the end of the experiment & 72,24 & 5,99 & 4,40 & 3,89 & 1,13 & $\mathrm{H}_{1}$ \\
\hline
\end{tabular}

It follows from the foregoing that the right to establish spiritual-moral foundations of improvement of professional educational activity of future teachers based on innovative axiological and system campaigns, with the growing dynamics of professional qualities and properties inherent in the professional educational activities of future teachers and dynamics of professional qualities of students at the end of the process of pedagogical practice up to $35 \%$ proves, that this leads to an increase in the quality and effectiveness of the educational process by $12-13 \%$ and getting a guaranteed result in the educational process.

\section{CONCLUSION}

1. The phenomenon of improving the spiritual-moral preparation of the future teacher for educational activities is a broad concept in which the national education inherent in the Uzbek people and the specific features of universal education have an integrated character. One of the urgent problems of the present time is that the teacher in the course of his daily activities is a specialist who educates the young generation in the spirit of scientific and moral qualities, as well as improving the system of spiritual-moral preparation for educational activities.

2. Modern state of professional educational activities of teachers, operating in the system of continuous education is determined through teacher observations and a questionnaire survey, interviews, comparisons, pedagogical methods, sociometry, justified by the pedagogicalpsychological need for improvement of educational activity of future teachers; for the first time from a scientific point of view rarity the contents and the essence of the concept "improvement of the system of spiritual-moral preparation of future teachers to educational activity."

3. Identified pedagogical conditions of spiritual-moral training of future teachers to educational activity in higher educational institutions; disclosed the contents and the essence of place "spiritually-moral education" in the 
pedagogical process, "the system of training to educational activities", "innovation-axiological approach", demonstrated features of systematization of pedagogical techniques and technologies.

4. Model structure improvement of educational activities of the future teacher of systematic, under the organic according to national and universal values, in the context of the technological system unity of upbringing and education, the specific objectives, the relationship of national and universal education, designated school "instructor-student", the introduction of innovative technologies guaranteed results, organic compliance with good thoughts, good words, good deeds, in practice, moral and professional excellence.

5. Innovative factors, methods and means of improving the spiritual-moral foundations of training future teachers for educational activities are developed, the professionogram of educational activity of the teacher-educator is improved and its effectiveness is determined on the basis of comparison, comparison, representativeness of experimental works and mathematical and statistical analysis of the results obtained.

6. A sequence of macro-modules was developed, consisting of a set of modules, including a module (small module) for preparing future teachers for educational activities, designed for one topic and one hour, a module block (primary module), consisting of a large topic, designed for several hours and components of a separate chapter, as well as integrated technologies.
7. Developed and implemented in practice the criteria for evaluating the experimental work carried out in this study based on scientific data on the increase in the characteristics of spiritual-moral training to the level of personal qualities such as patriotism, humanism, a sense of professional duty, love for children, tolerance, compliance with personal and professional qualities, social activity, erudition, the desire of the educator to innovations and creative abilities.

8. The growth of the dynamics of spiritualmoral professional qualities and properties inherent in the professional educational activity of future teachers and the dynamics of increasing the professional qualities of students at the end of pedagogical practice by $18.3 \%$ was determined. It is proved that with the correct establishment of spiritual-moral foundations for improving professional educational activities of future teachers on the basis of innovative axiological and systematic approaches, the quality and effectiveness of the educational process increases by 12-13 percent and leads to the achievement of guaranteed results in the educational process.

\section{REFERENCES}

1. Strategy of action for further development of the Republic of Uzbekistan. Decree of the President of the Republic of Uzbekistan. Collection of legal documents of the Republic of Uzbekistan, Article 70, № 6, 2017.
2. Abdukarimov H. Professional pedagogical activity. - T.: Teacher, 2010.- $60 \mathrm{p}$.




\section{Nurumbekova Ya. Innovation technologies in the educational profession. Educational methodical manual. Gulistan. Ziya. 2012.- p. 62.}

4. Slastenin V. A., Isaev I. F., Shiyanov E. N. General pedagogy. - Moscow: Vlados,2002.- 256C.

5. Terekhina L. A. Formation of pedagogical culture of the future teacher in the process of General pedagogical training. - Moscow: Pedagogy, 1996.- 216c.

6. Kuranov M. National education. Tashkent: Manaviyat, 2007.- p. 240.

7. Serikov V. V. Education and personality. Theory and practice of designing educational systems. - M.: IR. Logos, 1999.- $272 s$. 